\title{
Sustainable Supply Chain in the Agri-Food Sector in South-Italy as an Eco-Sustainability Tool for Innovation and Territorial Development
}

\author{
Giuseppe Colella ${ }^{1} \&$ Maria Teresa Paola Caputi Jambrenghi ${ }^{1}$ \\ ${ }^{1}$ Ionian Department of Mediterranean Legal and Economic Systems, University of Bari-Aldo Moro, Taranto, Italy \\ Correspondence: Giuseppe Colella, Ionian Department of Mediterranean Legal and Economic Systems, \\ University of Bari-Aldo Moro, Taranto, TA., 74121, Italy. E-mail: giuseppe.colella@uniba.it
}

Received: September 3, 2020

Accepted: October 16, 2020 Online Published: November 2, 2020

doi:10.5539/jms.v10n2p83

URL: https://doi.org/10.5539/jms.v10n2p83

\begin{abstract}
The agri-food logistics chains face guarantee the greatest extending of sustainability practices in the management of the entire supply chain. The use of management and marketing tools and of innovative legal and economic institutes, also in the agri-food sector, is fundamental to guaranteeing an increasingly "cleaner" agriculture, in order to introduce more and more organic and eco-sustainable food products and safe for the health and well-being of living beings on the market. However, the joint use of these tools does not yet seem to be fully exploited, particularly in South-Italy. In this sense, the territories limit of potential eco-sustainable development tools deriving from the agri-food logistics chains, also in terms of territorial and tourism development of entire areas. Drawing upon the experiences of innovative projects oriented to eco-sustainability that have implemented mechanisms of continuous improvement in the agri-food sector, through the achievement of high levels of technological, methodological and organizational innovation, some implications for how to implement territorial development policies guided by sustainability can be found. In this paper, the changes that the agri-food sector has undergone will be discussed and possible scenarios of territorial and tourism development supported by the agri-food logistics chains will be suggested, two macro areas covered by the three pillars of sustainability, environmental, economic and social.
\end{abstract}

Keywords: sustainable supply chain (SSC), sustainability, public procurement innovation (PPI), territorial development, agri-food logistics chains, territorial marketing

\section{Introduction}

In the last twenty years, the theme of sustainability has assumed great importance and has strongly changed the economic, social and environmental status quo on a global level (Pope, Annandale, \& Morrison-Saunders, 2004; Rama et al., 2020). As a result, the United Nations has committed itself to pursuing sustainable development targets through the Agenda 2030 action plan, where sustainability is framed as a key driver (Rama et al., 2020) and a clear judgment is expressed on the unsustainability of the current development model (Swart, Raskin, \& Robinson, 2004). The goal is to aim for a strategy that incorporates the three pillars of sustainability, balancing the dimensions of economic growth, social inclusion, and environmental protection (Gibson, 2006; Gupta \& Vegelin, 2016). In light of this, it has been recognized that the implementation of these strategies in certain territories will play a central role. These regions are called to face important challenges for their sustainable development (Barile et al., 2013; Paniccia et al., 2017; Ugolini, 2010) so that they guarantee a vigorous resilience to future adversity the populations residing there (De Rosa, 2019; Mazzeo, 2018). In this context, territorial systems must be able to withstand the complexity and speed of socio-economic, technological, and environmental changes that are taking place to ensure their survival (Colella, 2019). Therefore, considering the objectives set in the 2030 Agenda action plan, these regions must take care to implement fruitful development policies that integrate the concept of sustainability from different points of view, such as production, consumption, infrastructure, and innovation, so as to make them real sustainable communities.

From these preliminary considerations, we want to evaluate how the final goal of sustainable development for the growth and protection of certain territory can be achieved. In particular, in this paper we employ a proposal framework that uses different perspectives of management and of the legal-economic sphere. Emphasis is given on the issue of sustainable development of the territories passing through agri-food logistics chains, which are intended as targets of resilient, innovative, and sustainable territorial development (Berti \& Mulligan, 2016; 
Biolghini, 2019; de Oliveria Medeiros \& Pitassi, 2018; Nematollahi \& Tajbakhsh, 2020; Wiskerke, 2009). The scientific debate on this issue is constantly evolving and focuses primarily on the method of creating replicable innovative models, rather than on the organization of agri-food logistics chains capable of contributing to the achievement of sustainability objectives on different levels (Berti \& Mulligan, 2016; Cicatiello et al., 2012; Forte \& Siviero, 2009, 2010, 2013; Nematollahi \& Tajbakhsh, 2020).

In this study, we will discuss the experiences of innovative projects oriented towards eco-sustainability, which have achieved high levels of technological, methodological, and organizational innovation in the agri-food sector for the benefit of entire areas. In particular, Filiera Logistica e Organizzazione (FiLO) is considered to be an already operational project on the Italian national territory, which incorporates the issues of sustainability, and technological and organizational innovation into the agri-food logistics chains. The main objective of the FiLO network is to provide companies in the agri-food sector and the logistics supply chain with a high level of technological, methodological, and organizational innovation through the implementation of replicable models, as well as to promote sustainability through organizational efficiency in the agri-food supply chains. The successful realization of the FiLO network in such a complex context was achieved via a strong synergy between different tools, both managerial and legal-economic in nature, that led to the implementation of a logistics system capable of creating a sustainable supply chain. In addition, the most relevant legal-economic institutes (e.g., Public Procurement of Innovation and Public-Private Partenership) capable of concretely supporting the realization of these forms of sustainable territorial development were also used.

This paper aims to offer, on the one hand, a further contribution to the literature relating to sustainability in the agri-food supply chain and, on the other, interesting innovative proposals and possible scenarios of sustainable territorial development for Taranto (Puglia, Southern Italy), thereby highlighting the importance of these best practices to projects being implemented. It is interesting to note how Taranto- the Italian emblem of a community linked to the monoculture of steel and considered to be underdeveloped and unsustainable - has finally embarked on a development path that fully respects the sustainable development goals set in the Agenda 2030 action plan and the guidelines of the Green New Deal (the European strategy for the growth and transformation of the Union into a modern, resource efficient, and competitive economy). For these reasons, the paper aims to identify proposals capable of structuring a model of sustainable territorial development that synergistically uses management tools and economic law at a territorial level. The result of this analysis will offer opportunities to rethink models of sustainable territorial and tourism development through the creation of a sustainable agri-food logistics chain and the integration of territorial marketing policies. Policies of technological, methodological, and organizational innovation implemented within agri-food logistics chains are a main driver in rethinking territorial development, and also promote eco-sustainable tourism and tourism companies. Ultimately, our goals are to suggest innovative models that can be replicated at different levels when contextualized in various reference sectors.

This paper is organized as follows. Section two describes the theoretical background and discusses the literature relating to logistics and sustainable supply chain management in the agri-food sector. Section three highlights some possible sustainable territorial development scenarios supported by territorial and tourism marketing policies. Section four offers some economic legal guidelines to support the realization of these innovative projects oriented towards sustainability. Finally, section five draws conclusions on the correct implementation of sustainable territorial development policies in agri-food logistics chains.

\section{Theoretical Background}

\subsection{Logistic Supply Chains and Logistics Outsourcing in Agri-Food Sector}

The phenomenon of globalization has substantially changed the national and international economic situation (Vaccà \& Cozzi, 2002) and has been a key driver of the development of international trade (Valdani \& Bertoli, 2006; Grandinetti \& Rullani, 1996). Of course, this has led to a strong intensification of international exchanges in which companies increasingly focus on the total availability of their products throughout the year, greatly increasing the strategic importance of logistics, both for the purposes of their competitive positioning and to preserve their identity in a global and open market (Ali et al., 2019; De Martino, 2012; De Martino et al., 2015; Forte \& Miotti, 2015; Marcucci, 2002).

Logistics is of great interest to both scholars and managers regarding the implementation of innovative development policies, as it represents a solid strategic lever for companies and for certain territories of various countries (Ali et al., 2019; Pulina \& Timpanaro, 2012; Rifai \& Hashem, 2018). The services offered by the logistics companies tend to integrate core, additional, operational, and strategic information services (Rifai \& Hashem, 2018) to ensure maximum efficiency of the logistics system (Ali et al., 2019). In particular, among the 
various sectors committed to ensuring maximum levels of efficiency from a logistical point of view, a central role is assumed by the agri-food industry (Verdouw et al., 2015). Logistics tends to be linked to a network of companies belonging to the same sector (Cerruti \& Musso, 2004) and must be able to adapt to the current economic paradigm, which is characterized by its disruptive and continuous evolution, both at process and at service level (Forte \& Miotti, 2015). Therefore, it is necessary to consider the technological and organizational implementation of innovative management models, which are capable of withstanding the continuous modifications of the logistics networks of the agri-food chain (De Martino, 2012; Forte \& Miotti, 2015; Van der Vorst et al., 2005).

From the point of view of sustainability, and in particular from the environmental point of view an important role is played by the cold chain for perishable food products, which includes the activities of selection, classification, washing, drying, pre-cooling, storage, and distribution (Babagolzadeh et al., 2020; Vreat et al., 2018). In this context, perishable and short-life food products (e.g., fresh fish and processed meat products) require temperature-controlled food supply chains (Göransson et al., 2018) and the challenges associated with the supply of such products in a safe way, ensuring high quality to the market, prove to be crucial. In fact, the production of food that passes from the farm to the consumer through a multi-level logistic system outside the cold chain is often subject to manipulation and exposure in open and uncontrolled environments, negatively impacting quality (Vreat et al., 2018). We note that in order to guarantee the safety and quality of food, the reference regulations play a significant role in strengthening the application of innovative technologies and cutting-edge managerial approaches suitable for the best management of the cold chain for perishable food products (Zanoni \& Zavanella, 2012). Therefore, considering that modern food supply chains are one of the most damaging in terms of environmental impact (Gallo et al., 2017), it is necessary to rethink traditional management models. In particular, a future line of research could address the adoption of management models implemented through the technologies of industry 4.0, which are capable of minimizing consumption and waste, and making food supply sustainable.

To better understand the role of logistics in achieving a sustainable food supply chain, it is interesting to highlight the importance of the agri-food sector at the Italian national level. The latest study by The European House-Ambrosetti (2019) shows that food consumption in Italy contributes to $14.1 \%$ of Gross Domestic Product (GDP) representing $23.2 \%$ of the country's total consumption with a value of around $€ 242.9$ billion in 2018 . The study adopts an approach that follows the various stages of making a food product, starting from the raw material up to its distribution to the final consumer and identifies five sectors that give life to the so-called extended agri-food chain: (1) agriculture, forestry, and fishing, (2) food processing, (3) brokerage, (4) distribution and (5) catering (The European House - Ambrosetti, 2019). Thus, it emerges that logistics today is no longer limited to the mere production and transformation of the agri-food industry, but integrates activities relating to intermediation, distribution, and catering within the agri-food logistics chain. Logistics extends and generates an agri-food industry, which already has a turnover of $€ 538$ billion, an export supply chain of approximately $€ 42$ billion, and employs approximately four million people. It thereby also increases the value of the supply chain (Pulina \& Timpanaro, 2012, The European House - Ambrosetti, 2019).

The figure below shows how the extended agri-food logistic chain generates the highest revenue among the extended Made in Italy supply chains. 


\section{La filiera agroalimentare estesa genera il più alto fatturato tra le filiere estese del Made in Italy}

Fatturato nelle filiere estese delle "4A" del Made in Italy in Italia (milioni di Euro), 2017

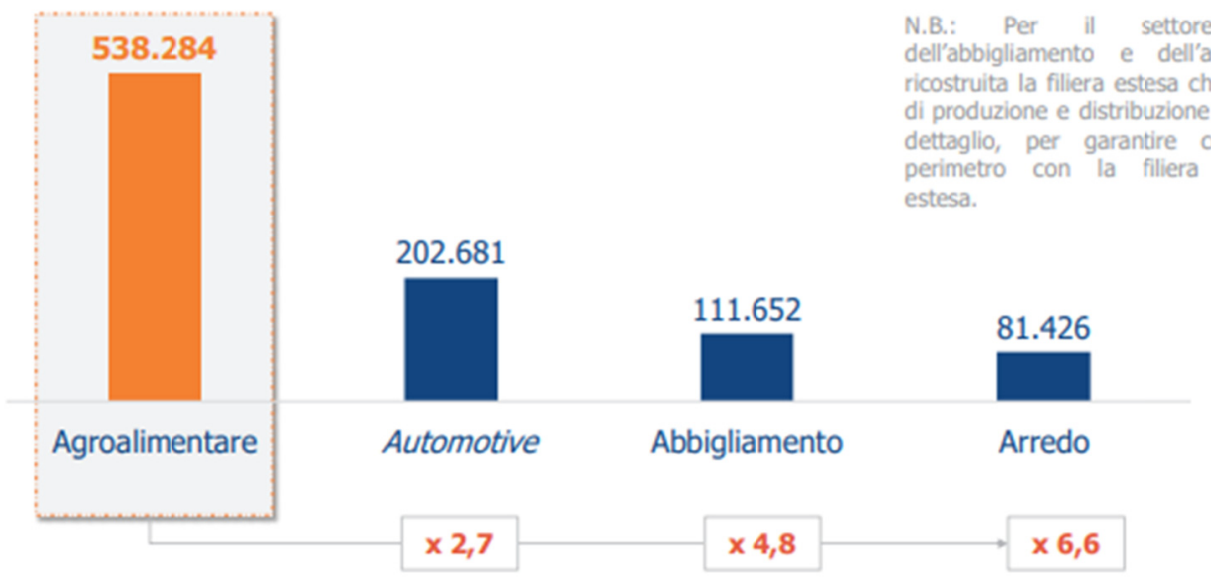

Figure 1. Turnover in the extended Made in Italy supply chains in Italy

Note. The graph relates the turnover of the "4 A" of Made in Italy (Agri-food - "Agroalimentare", Automotive, Clothing - "Abbigliamento" and Furnishings - "Arredo"), The extended chain has been reconstructed for the four supply chains and includes the production and distribution phases wholesale and retail, to ensure comparability of the perimeter with the extended agri-food chain.

Source: The European House, Ambrosetti, 2019.

Givrn this extension of the agri-food logistics chain and its strategic relevance from a sustainable point of view, logistics outsourcing plays a specific role in this context. In fact, there is a great body of literature regarding logistics outsourcing (De Martino, 2012; Forte \& Miotti, 2015; Hsiao et al., 2006; Hsiao et al., 2010; Razzaque \& Sheng 1998; Rifai \& Hashem, 2018; Van Damme \& Van Amstel, 1996), which includes, in addition to the traditional activities related to transport and storage (Rifai \& Hashem, 2018), activities relating to the entire organizational system in which marketing activities fall. By adopting logistics outsourcing, large industries focus their energy only on the main activitiesthat enable them to survive global competition (Ali et al., 2019). As discussed by Hsiao et al. (2010), logistics outsourcing in the agri-food chain divides and identifies the activities connected to it in execution and planning. Moreover, outsourcing identifies different levels of involvement of the logistics operators, such as the simple execution of executive transport activities in full outsourcing, or outsourcing global logistics relating to the management of orders, transportation, and marketing activities, etc. (De Martino, 2012). Therefore, it is of primary importance to create a synergistic system of cooperation between the different levels of activity of the operators present in the agri-food logistics chain, which make up a large, complex, and shared distribution network.

\subsection{Sustainable Supply Chain Management and Innovation in Agri-Food Sector}

Considering the entire logistics system from a sustainable perspective, companies in the agri-food chain must also take into account a sustainable supply chain management (SSCM) system. Sustainability today is a key point in the development of entrepreneurial strategies (Ahi \& Searcy, 2013) aiming to make organizations more resilient through the integration of the three dimensions of sustainable development: social, environmental, and economic (i.e., the Triple Bottom Line (TBL) approach - Nikolaou, Evangelinos \& Allan, 2013). The concepts of sustainability and supply chain management have created an interesting debate in the literature (Seuring et al., 2008), which has increased the degree of integration between the two concepts over time (Ashby et al., 2012; Ahi \& Searcy, 2013; Baah \& Jin, 2019).

According to Seuring and Müller (2008), the management of flows of materials, information, and capital, as well as the cooperation between companies along the entire supply, transformation, and distribution chain, are required to integrate the objectives of the three dimensions of sustainable development. Ahi and Searcy (2013), in their analysis of the literature, offer a more complete definition of SSCM, defining it as "The creation of coordinated supply chains through the voluntary integration of economic, environmental, and social considerations with key inter-organizational business systems designed to efficiently and effectively manage the 
material, information, and capital flows associated with the procurement, production, and distribution of products or services in order to meet stakeholder requirements and improve the profitability, competitiveness, and resilience of the organization over the short- and long-term" (Ahi \& Searcy, 2013, p. 339). In agreement with Naik and Suresh (2018), the SSCM in the agri-food sector invests all those activities along the chain from production, transformation, distribution, and retail to the final consumer, and represents a globally interconnected system characterized by complex relationships. Furthermore, this system tends to influence the method of production, transformation, and delivery of food on the market (Burch \& Lawrence, 2005). Therefore, in order to achieve an SSCM that minimizes the environmental impact of all phases of the supply chain, it is important for companies to guarantee increasingly safe and certified products and services (Corallo et al., 2020), which are capable of addressing an increasingly relevant and informed final question (Govindan, 2018).

The constant evolutions that have affected the agri-food chain have pushed company networks to rethink their management models of logistics, making it increasingly extended, innovative, and sustainable from a technological, organizational, and strategic point of view (Baah \& Jin, 2019; Corallo et al., 2020). This new approach tends to consolidate relationships and encourage the emergence of new forms of collaboration between companies operating within the same chain. Technological innovation within the industrial sector undoubtedly plays a leading role in this evolution process (Meynard et al., 2017; Saetta \& Caldarelli, 2020). In particular, agri-food systems need innovation to achieve sustainability (Tilman \& Clark, 2015; Meynard et al., 2017) making logistics an ever more important strategic, complex, and computerized lever (Corallo et al., 2020). The management principles of the entire supply chain system also have to adapt to the current highly technological and computerized context. They must constantly seek cutting-edge solutions, such as the optimization of production processes, the reduction of costs internal to companies, the outsourcing of various activities and the increase in the overall efficiency of the agri-food logistics chain. This will make them more innovative and sustainable from an environmental, economic, and social point of view. Therefore, as already highlighted, logistics and the complex system of SSCM continue to be of great interest as they are important strategic levers for development, and are intrinsically connected to the divergent issues of territorial development, public-private interventions affecting infrastructure, and the impact that they have on employment with significant socio-economic effects (De Martino, 2012; Mazzeo, 2010, 2018). It is therefore clear that the entire system of the agri-food logistics chain can profitably intersect other sectors, such as territorial marketing, to support development from a global perspective of the territory.

\section{Method}

In this paper, a descriptive methodology and exploratory research method is used, mostly based on reviewing academic literature on the experiences of innovative projects implemented on the Italian national territory that are oriented towards the eco-sustainability of the agri-food chain. In particular, this research aims to offer possible territorial development scenarios for South-Italy, considering specifically the city of Taranto (Puglia, South-Italy). These development scenarios are based on experiences and are supported by literature. We examine the importance of sustainability in the agri-food SSCM, in particular by evaluating the possible consequences that the logistics supply chain can have in terms of the development of entire territorial areas, such as to ensure high levels of resilience to damages. In this context, the contribution of the territorial marketing and economic law disciplines is relevant. Overall, the analysis is guided by the following two research questions:

RQ1: How can agri-food SSCM guarantee high standards of sustainability, territorial development, and urban resilience?

RQ2: Which legal-economic institutions can be considered to support the implementation of innovative projects oriented towards sustainability?

\section{Results and Discussion}

In this section we present the results of our exploratory research and provide a general discussion indicating the possible development scenarios and tools to support the implementation of specific innovative and sustainable projects. Two projects implemented on the Italian national territory (i.e., FiLOand FICO Eataly World) will be briefly illustrated, which serve as a basis to obtain interesting insights for the city of Taranto. When answering the research questions, two thematic areas are considered. Firstly, with reference to $R Q 1$, territorial and sustainable tourism marketing strategies and policies are proposed. Secondly, with reference to $R Q 2$, the public procurement of innovation in an eco-sustainable economy is considered. 


\begin{abstract}
Box 1. Experience «FiLO - Filiera Logistica e Organizzazione»
The first design experience we took into consideration is the evolution state of an innovative project implemented on the Italian national territory, «FiLO - Filiera Logistica e Organizzazione», financed with EU public funds (i.e. PSR 2014-2020 - Measure 16 - Sub Measure 16.1 "Support for the establishment and management of PEI Operational Groups in the area of productivity / sustainability of agriculture Umbria region, Italy) which has as its main objective to bring to the network of agri-food businesses and in the logistics chain a high level of technological, methodological and organizational innovation, through the implementation of replicable models. First, FiLO project implemented an internal logistics optimization system, these are that set of specific activities that take place inside and between the plants, through careful work to improve efficiency at each stage of production; second, it introduced a control and management system within the network partner companies. Therefore, it intended to develop a shared distribution platform through the use of Information Technologies tools; finally, it was intended to frame a form of common supply contracts along the entire regional chain. The analysis showed that different managerial scenarios emerge to be considered to support the entire logistics system, attributable to sustainable supply chain management.
\end{abstract}

Source: https://www.retefilo.eu/page.php?idp=1

\title{
Box 2. Experience «FICO - Eataly World»
}

The second design experience we took into consideration regards the «FICO - Eataly World» (Fabbrica Italiana Contadina), the largest agri-food park in the world dedicated to biodiversity and the art of transformation of the made in Italy product. The project was born from the idea of converting a logistic plate dedicated area into something bigger. Thus, through a public-private partnership, the most exciting food park in the world began to take shape, capable of guaranteeing a unique journey through the flavors of the Bel Paese, where living food is an experience, exploring its productions a discovery. The executive design of the civil, structural and plant engineering works, of the client's layouts, and checks of all regulatory, technical, logistical and organizational aspects, followed a purely centered orientation towards sustainability. In fact, the «FICO - Eataly World» plant project achieves high energy and environmental standards, thanks to the introduction of magnetic levitation refrigeration units with very high partial load efficiencies, with the connection to the existing district heating system and the use of the electricity produced from the photovoltaic system installed on the roof. In addition, the plant framework is completed by LED lighting and an advanced regulation system, which optimizes energy consumption based on actual requests. Therefore, also from the analysis of this innovative project, different territorial development scenarios attributable to the agri-food sector emerge.

Source: https://www.politecnica.it/progetti/parco-agroalimentarefico-eataly-world/ - https://www.eatalyworld.it/it

\subsection{Marketing Prospects for the Development of the Territory and the Promotion of Sustainable Tourism}

Driven by the advancement of technological innovation and the new challenges that they are called to face in a Specific, Measurable, Achievable, Realistic e Time-Based (SMART) (Drucker, 1954) and sustainable manner, the modernization of certain territories has had a strong impact on the identification of new areas for economic growth, leading to the development of new study guidelines in terms of marketing (Montella \& Silvestrelli, 2020; Tovma et al., 2020). In this context, academic research is increasingly focused on studying innovative territorial development solutions through territorial marketing, placing it as a real strategic planning tool (Guido, 2017) capable of determining advantageous opportunities and conditions that strengthen its competitiveness (Colella, 2019; Deffner \& Metaxas, 2010). On the basis of previous literature, the entire agri-food SSCM system is imposing precise choices in terms of territorial marketing policies and actions, which could represent important drivers of development for a territorial agri-food logistics macro system capable of measuring the competitiveness of a territory from different points of view.

According to Kotler et al. (1993), territorial marketing represents that set of collective actions put in place with the aim of making a specific territory attractive to new economic and productive activities. This favors local entrepreneurial development, increasing their ability to attract external resources (Pike et al., 2017; Renigier-Biłozor \& Biłozor, 2015; Tovma et al., 2020), and outlines a process of formulating marketing and strategy branding that is both responsible and territory specific (Pino et al., 2018). Starting from these assumptions in a context strongly linked to the creation of an agri-food territorial logistic macro system, it is important to identify the levers on which to rely. For example, the creation of Distriparks, state-of-the-art logistic poles, logistic axes at the service of important large areas, and large-scale distribution (Large Organized Distribution) in areas with a high rate of urbanization are important factors. Above all, the realization of urban regeneration processes supported by incisive territorial marketing policies is key (Forte \& Siviero, 2009). With this in mind, the creation of a territorial agri-food logistics chain should suggest innovative development models in order to obtain territorial development strategies that follow the logic of marketing, sustainability, and 
technological innovation. This will lead to the creation of a network not only linked to the agri-food sector, but to the entire economic and social fabric of a territory.

The extension of the agri-food logistics chain in recent decades has produced various effects from an environmental, economic, and social point of view (De Fazio, 2016). Indeed, several studies have identified a series of indicators related to territorial marketing in the logistics context, such as innovation, labor costs, infrastructures, and the supply chain management system (Comino \& Ferretti, 2016; Danko et al., 2016; Popović et al., 2018; Tovma et al., 2020), which through a perfect synergistic activity are able to guarantee an overall efficiency of the whole system. Although a territorial agri-food logistics system is made up of actors and institutions with different visions and objectives regarding the production, transformation, distribution, and consumption of food products on a territorial scale, they are configured as interdependent subjects (Lamine et al., 2019). All the actors that work together for the development of the territory are recognized as having a central role in the application of best practices, which create added value in the environmental, economic, and social dimension. Moreover, this leads to the valorization and promotion of the territory, which ensures a social balance and a continuous growth in the territory's attractiveness (Colella, 2019; Pastore et al., 2002). Therefore, considering the need to incentivize processes of valorization and promotion of the territory, it is necessary to integrate sustainable territorial marketing policies and actions into tourism marketing, where the aim is to develop a series of joint actions (Colella, 2019).

In the last decade, tourism territories have increasingly directed their promotion strategies towards gastronomy and local products (Liu et al., 2017; Tanasă, 2014). This has impacted the growing extension of networks erected on local agri-food products and revitalized territorial agri-food markets. From this perspective, the presence of an efficient agri-food SSCM system could offer local farms the opportunity to implement interesting rural development projects in the fields of education, leisure, adventure, and travel, thereby creating an attractive place for the development of a sustainable tourism supply chain (Liu et al., 2017; Rinaldi \& Cavicchi, 2016). It is therefore a matter of promoting agri-food tourism through an eco-sustainable strategy that is guided by the innovation of supply chain management systems, such that they are capable of meeting the needs of specialized consumers. In addition, management systems must remain faithful and sensitive to the dimensions of sustainable development (Campón-Cerro et al., 2017; Corallo et al., 2020; Govindan, 2018), and make use of the benefits offered by the entire logistic structure present in the territory to improve the local image as a whole.

Insight 1: The territories should implement territorial development policies capable of increasing their attractiveness to potential stakeholders in economic, social, and environmental terms, pursuing a logic linked to the concepts of sustainability and innovation. Furthermore, a solid system of agri-food SSCM should positively affect the infrastructure in the area, as well as lead to the development of a resilient network formed by secondary activities present within it, facilitating their long-term sustainability.

Insight 2: The implementation of sustainable tourism policies requires the participation of both public and private actors (Campón-Cerro et al., 2017). Therefore, a solid infrastructural system of the entrepreneurial fabric of the agri-food sector, and effective activities of sustainable territorial, tourist, and rural promotion could guide the territories towards a consolidation of their image and reputation as resilient, clean, innovative, and virtuous.

\subsection{Public Procurement of Innovation as a Tool for Innovation in an Eco-Sustainable Economy}

In this section, we discuss the instruments that the legal system makes available to administrations and business networks for the implementation of territorial management strategies inspired by innovation. These management strategies aim to promote effective services, sustainable supply chains, and logistic tools for their environmental, social, and economic impact. One important, though still little used and poorly understood tool is known as the Public Procurement of Innovation (PPI), which specifies procurement procedures for innovation.

The FiLO project used a PPI tool, in particular the partnership for innovation (data under art. 65 of the code of contracts contained in Legislative Decree 50/2016, including subsequent modifications and additions). This is a much-discussed regulatory text and for this reason is subject to continuous changes. These changes envisaged the creation of a series of institutes, or the strengthening of those already existing, to generate a significant contribution towards innovation within the public sector administration through demand for public-works, services, and supplies. The benefit of innovative public procurement is, in fact, that of saving in economic or environmental terms.

Consequently, the ultimate goal of public procurement is to find resources from the market that are not usable within public administrations, and thereby optimize the quality of public spending via a constant balance 
between user/citizen needs and the use of resources available. Indeed, in the various procedures that the code governs for obtaining innovative solutions, the contracting authority must pay particular attention to the formulation of the functional and performance requirements of the operators, as well as to the criteria for assessing the quality and, possibly, provision of prototyping. Here, we refer to the competitive procedure of negotiation, the competitive dialogue, the design competition, and the Pre-Commercial Procurement, all of which offer public buyers greater flexibility in awarding contracts, as well as the opportunity to find innovative solutions immediately available on the market. Finally, procedures having the undisputed advantage of bringing public purchasers closer to industry favor a direct dialogue on the specific characteristics that innovative solutions must offer to meet the purchaser's needs.

The innovative potential of these procedures can be traced precisely to the wide range of proposals that the invited economic operators can present to satisfy the contracting authority's demand for innovative solutions. Indeed, as part of such an accurate and thorough negotiation, candidates should have the time to acquire all of the relevant information, thanks to which they can provide one or more innovative customized solutions.

It very often happens that public buyers contract Research and Development (R\&D) services due to the lack of suitable solutions on the market in terms of innovation and $R \& D$, or due to the inability of existing solutions to address the specific needs of the contracting authority. Indeed, choosing the procurement of R\&D services represents a valid option for all public buyers who intend to introduce a revolutionary innovation to the market, or to adopt an innovative solution present in another sector to their advantage. These are, in fact, contracts for all services relating to scientific progress obtained in various fields of the natural or social sciences, including basic research, applied research, and experimental development. Through this procedure, the administration becomes the exclusive owner of the models produced, so the procurement of R\&D services does not allow the acquisition of a model that can be replicated by companies or business networks. It is therefore evident that in the illustration of the various PPI tools, the one that best suits the needs described in this analysis should be identified. The focus should be on the distribution of costs and results between the client and the service provider. Then, a model can be designed that can be replicated by businesses and administrations, and achieves the proposed objectives in the most disparate sectors of not only the market, but of life in civil society more generally.

The institute of the partnership for innovation used in the FiLO project is a public procurement procedure that can only be used in the event that the needs of public buyers cannot be met by resorting to solutions already available on the market. This case is governed by art. 65 of the code of contracts contained in Legislative Decree $50 / 2016$, including subsequent modifications, additions, and concerns, not only regarding R\&D, but also the large-scale marketing of final products and/or services. Unlike other procedures, the peculiarity of the partnership for innovation lies in the fact that the entire innovative process takes place during the execution of the contract itself. In other terms, it can be said that the partnership for innovation represents one of the tools that contributes the most to the pursuit of innovation and environmental protection. This is a particular form of public-private partnership that gives rise to a special and flexible tender procedure for the award of complex, long-term, and innovative procurement contracts, especially with respect to the competitive procedure of negotiation.

Although the challenge of innovation in the Italian legal system is particularly difficult due to the lack of awareness and low usage of this innovative tool for improving the territory and the life of the community, it is believed that this brief exposition of the tools made available by the legal system can initiate the implementation of good practices in the administration. This will enable the simplification of procedures, greater flexibility, and functional adaptation to public sector policies, as well as the possibility to obtain a better quality-to-price ratio. Ultimately this can make public procurement more efficient and strategic for the benefit of public buyers, economic operators, and the whole of civil society.

\section{Innovative Proposals and Possible Development Scenarios in a Real Context: Taranto (Puglia, Southern-Italy)}

The experiences of the design reality of FiLO and FICO, and the analysis of the literature of management tools and of economic law to support the realization of sustainable agri-food logistics chains have suggested possible scenarios and paradigm innovations that can be replicated at different levels in a real context, namely the city of "Taranto". Taranto represents the Italian emblem of a community linked to the monoculture of steel and is considered underdeveloped and unsustainable due to a retrograde industrialized vision deeply in crisis. However, over the past few years, it has embarked on a development path that is fully inspired by the principles of sustainable development contained in the Agenda 2030 action plan and in the Green New Deal lines, resulting in 
a total rethinking of the development model pursued so far. Consequently, various territorial development actions have been implemented to date in the economic, social, and environmental fabric (Berardi \& Castronuovo, 2017; Colella, 2019); in particular, as part of the development of a territorial agri-food logistics chain, Taranto has several ambitious and innovative projects within it, such as Agromed, although they have not yet been implemented.

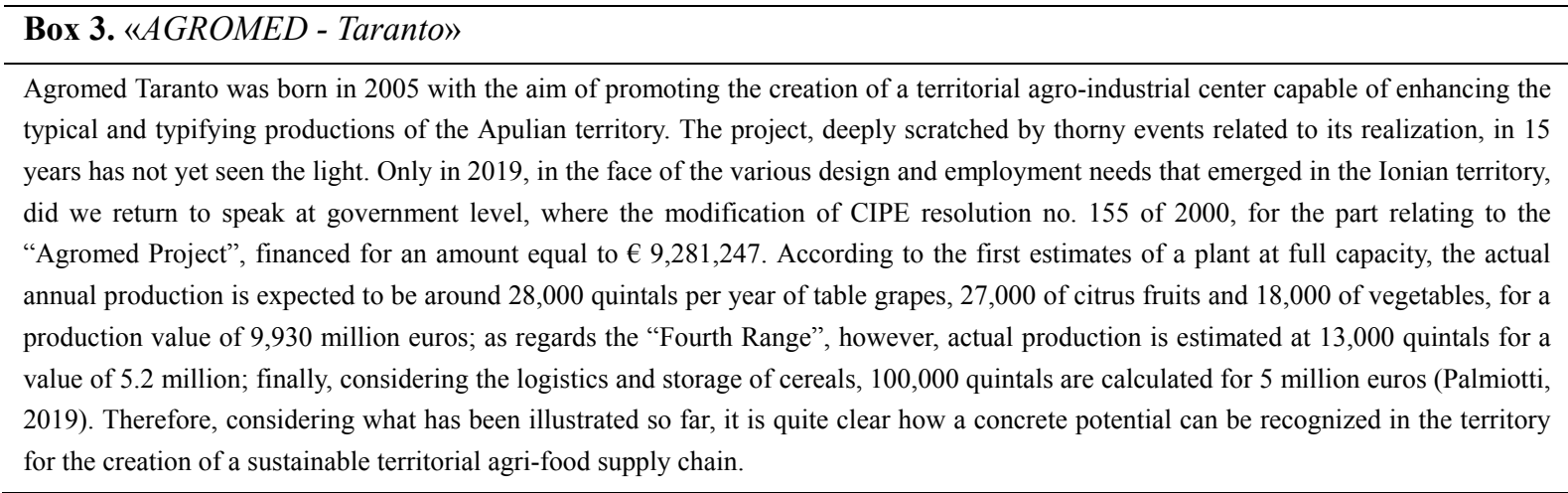

In a broad context, the presence of several excellent production chains within a given territory rives the integration of logistical activities within the complex supply chain management system, which is of great value for import and export flows (Forte \& Miotti, 2015). The analysis of the agri-food chains in the territories suggests that the presence of logistic levers plays an essential role. These logistic levers include Distriparks, ports, retroport areas, and logistic axes that act as landing, boarding, transport, and storage areas of the products and commodities, and they support the smooth functioning of the entire supply chain management system. Furthermore, technological and organizational innovation in the logistics sector has allowed, on a global level, a profitable extension of the supply network of companies within the chains (Forte \& Miotti, 2015). A forward-looking example in this sense is the FiLO project, the actuator of technological transfer, consultancy, and traceability of movements through IT tools of extreme relevance. In light of this, we offer a first proposal of innovative action to support territorial development in Taranto.

Propose 1: For the creation of a sustainable agri-food logistics chain in the Taranto area, it is deemed appropriate to consider the implementation of innovative tools and concrete synergies between public and private entities to support the entire organizational structure. From what is highlighted in box 3, the Taranto area could implement innovative technology transfer policies in the organization of its sustainable territorial agri-food supply chain, both in terms of process and product, as well as in terms of service, by synergistically cooperating with scientific researchers, institutions, and entrepreneurs. Changes could also be driven by the new institution of the Mediterranean technopole for sustainable development and innovation. In addition, economic instruments capable of implementing innovation at all levels, such as public funds made available by the various levels of government and private resources, are granted by companies wishing to innovate in a highly competitive context where innovation is the main driver.

Considering a broader vision of the phenomenon of the creation of a sustainable agri-food logistics chain in the context of Taranto, a fundamental role is assumed by the instruments of management and economic law analyzed so far at the territorial level. Starting from the creation of a sustainable agri-food logistics chain, Taranto could rethink, or readjust, its territorial development model to be consistent with the objectives of sustainable development by implementing incisive territorial marketing policies. In light of this, we offer a second innovative proposal to support territorial development in Taranto.

Propose 2: Technological, methodological and organizational innovation implemented within the territorial and sustainable agri-food logistics chains could represent a driver of territorial development through eco-sustainable tourism. This would promote loyalty to the destination within a framework of sustainable development, especially in rural contexts. Furthermore, it would be interesting to design an agri-food tourist attraction centre in Southern Italy. It would be interesting even for agricultural businesses in the area to replicate these innovative models contextualized in the various reference sectors and, ultimately, to evaluate the opportunity to integrate activities and services other than 
those of the agri-food production sector, in order to expand the territorial tourist offer from a sustainable perspective.

\section{Conclusion}

The goal of this analysis was to understand and explore how the implementation of innovative tools for eco-sustainability within the agri-food logistics chain is spreading throughout the Italian national territory. It emerged that the transformations that logistics has undergone in the last decade have profoundly contributed to changing its entrepreneurial approach. Logistics has become a real strategic endeavour, especially in the competitive context of agri-food companies. Furthermore, the deepening of these concepts in both a theoretical and entrepreneurial vision allowed us, firstly, to identify the methodologies already applied on the Italian territory (i.e., the FiLO project and FICO), and secondly, to examine the implications of state-of-the-art literature in the fields of management, marketing, and economic law for the sustainable development of agri-food logistics systems. Thirdly, the analysis allowed us to offer possible scenarios of territorial and touristic development linked to the creation of a territorial agri-food logistics chain within a real context, such as Taranto (e.g., the Agromed project).

The strong awareness of environmental issues and sustainable development that oversees the implementation of incisive development policies at the political, economic, social, and entrepreneurial level is also affecting the processes of logistics and mobility of goods. In the agri-food logistics chain, sustainability is now taking on a central role, becoming a real development driver in the entire process. On the other hand, sustainable logistical-territorial development in a context such as that of Vast Areas could generate significant socio-economic impacts, leading to a transition model of underdeveloped areas that could be favoured by suitable territorial marketing tools. From this perspective, there would be a change in the economic and managerial culture of the territory through a greater diffusion of the logistic culture. It is clear that the involvement of public institutions, high schools, and universities is necessary, both to aid the process of identifying best practices that support the entire system, as well as to train professional figures capable of integrating perfectly into this new economic-entrepreneurial culture.

The FiLO project could represent a valid example of the development of an agri-food logistics supply chain in the Taranto Vast Area (South-Italy) that integrates sustainability, in its broadest sense, and technological innovation. It is precisely for these reasons that projects such as Agromed and Distripark should be considered as important development levers for Taranto, not only from the point of view of the agri-food logistics chain, but also with reference to territorial and tourist development; two sectors presided over by the three pillars of environmental, economic, and social sustainability. Finally, the Taranto case could act as an example of radical industrial reconversion by rethinking its model of territorial development, starting precisely from innovative projects concerning the sustainable agri-food logistics chain. This would lead to the creation of a reconversion process capable of promoting urban resilience.

\section{Acknowledgments}

The authors would like to thank Editor and Reviewer for the interest shown in our contribution. Although the article is the result of the joint work of the two authors, paragraphs 1, 2, 2.1, 2.2, 3, 4, 4.1, 5 and 6 are attributed to Giuseppe Colella and paragraphs 1, 4.2 and 6 to Maria Teresa Paola Caputi Jiambrenghi.

\section{References}

Ahi, P., \& Searcy, C. (2013). A comparative literature analysis of definitions for green and sustainable supply chain management. Journal of Cleaner Production, 52, 329-341. https://doi.org/10.1016/j.jclepro.2013.02.018

Ali, A., Chauhan, K., Barakat, M., \& Eid, A. (2019). The Role of Sustainability for Enhancing Third-Party Logistics Management Performance. Journal of Management \& Sustainability, 9, 14. https://doi.org/10.5539/jms.v9n1p14

Ashby, A., Leat, M., \& Hudson-Smith, M. (2012). Making connections: a review of supply chain management and sustainability literature. Supply Chain Management: An International Journal, 17(5), 497-516. https://doi.org/10.1108/13598541211258573

Baah, C., \& Jin, Z. (2019). Sustainable supply chain management and organizational performance: The intermediary role of competitive advantage. Journal of Management \& Sustainability, 9, 119. https://doi.org/10.5539/jms.v9n1p119

Babagolzadeh, M., Shrestha, A., Abbasi, B., Zhang, Y., Woodhead, A., \& Zhang, A. (2020). Sustainable cold 
supply chain management under demand uncertainty and carbon tax regulation. Transportation Research (Part D: Transport and Environment), 80, 102245. https://doi.org/10.1016/j.trd.2020.102245

Barile, S., Saviano, M., Polese, F., \& Di Nauta, P. (2013). Il rapporto impresa-territorio tra efficienza locale, efficacia di contesto e sostenibilità ambientale. Sinergie Italian Journal of Management, 90, 25-49. https://doi.org/10.7433/s90.2013.04

Berardi, G., \& Castronuovo, V. (2017). Il "convicinio" di Sant'Andrea degli Armeni a Taranto: un bene relazionale, oltre che culturale, Ricerche e progetti per il territorio. la città e l'architettura, 8(11), 490-499. ISSN 20361602

Berti, G., \& Mulligan, C. (2016). Competitiveness of small farms and innovative food supply chains: The role of food hubs in creating sustainable regional and local food systems. Sustainability, 8(7), 616. https://doi.org/10.3390/su8070616

Biolghini, D. (2019). Terra e Cibo, per costruire una comunità resiliente. Scienze del Territorio, 7, 168-177.

Burch, D., \& Lawrence, G. (2005). Supermarket own brands, supply chains and the transformation of the agri-food system. International Journal of Sociology of Agriculture and Food, 13(1), 1-28.

Campón-Cerro, A. M., Hernández-Mogollón, J. M., \& Alves, H. (2017). Sustainable improvement of competitiveness in rural tourism destinations: The quest for tourist loyalty in Spain. Journal of Destination Marketing \& Management, 6(3), 252-266. https://doi.org/10.1016/j.jdmm.2016.04.005

Cerruti, C., \& Musso, F. (2004). La logistica nei distretti industriali. Scenari di evoluzione per l'integrazione delle filiere, Finanza. Marketing e Produzione, 22(4), 23-40. https://doi.org/10.2139/ssrn.2479974

Cicatiello, C., Pancino, B., \& Franco, S. (2012). Un modello per la valutazione della sostenibilità territoriale delle filiere agroalimentari: struttura e applicazione alla sfera ambientale. 1st AIEAA Conference-Towards a Sustainable Bioeconomy: Economic Issues and Policy Challenges (No. 1051-2016-85881).

Colella, G. (2019). Competitività e sviluppo dei territori nel mediterraneo. Un approccio integrato alla funzione di marketing. Annali del Dipartimento Jonico in sistemi giuridici ed economici del Mediterraneo: Società, Ambiente, Culture, 7, 137-152.

Corallo, A., Latino, M. E., Menegoli, M., \& Striani, F. (2020). What factors impact on technological traceability systems diffusion in the agrifood industry? An Italian survey. Journal of Rural Studies, 75, 30-47. https://doi.org/10.1016/j.jrurstud.2020.02.006

De Fazio, M. (2016). Agriculture and sustainability of the welfare: the role of the short supply chain. Agriculture and Agricultural Science Procedia, 8, 461-466. https://doi.org/10.1016/j.aaspro.2016.02.044

De Martino, M. (2012). La gestione della logistica nelle filiere agroalimentari: alcune evidenze empiriche in Campania. Economia agro-alimentare, 14(2), 41-62.

De Martino, M., Carbone, V., \& Morvillo, A. (2015). Value creation in the port: opening the boundaries to the market. Maritime Policy \& Management, 42(7), 682-698. https://doi.org/10.1080/03088839.2015.1078010

de Oliveria Medeiros, T. D. F., \& Pitassi, C. (2018). Eco-Innovation in the Corporations Operating in the International Market. Journal of Management \& Sustainability, 8, 75. https://doi.org/10.5539/jms.v8n1p75

De Rosa, M. (2019). La sostenibilità e lo sviluppo sostenibile nell'economia agroalimentare e nello sviluppo rurale. Connessioni per lo sviluppo sostenibile, 32.

Deffner, A., \& Metaxas, T. (2010). Place marketing, local identity and branding cultural images in Southern Europe: Nea Ionia, Greece and Pafos, Cyprus. In G. Ashworth \& M. Kavaratzsis (Eds.), Towards Effective Place Brand Management (pp. 49-68). Cheltenham: Edward Elgar. https://doi.org/10.4337/9781849806398.00010

Forte, E., \& Miotti, D. (2015). L'outsourcing, la terziarizzazione dei trasporti e delle logistiche nelle filiere traslog (Vol. 29). In 17th annual conference of SIET (Società Italiana di Economia dei Trasporti e della logistica).

Forte, E., \& Siviero, L. (2010). Modelli di trasformazione del territorio in metropoli e filiere territoriali logistiche. Sistemi di Logistica, 1, 7-15.

Forte, E., \& Siviero, L. (2013). Trasformazione logistica e città metropolitane del Mezzogiorno. Rivista Economica del Mezzogiorno, 27(1-2), 121-154. 
Gallo, A., Accorsi, R., Baruffaldi, G., \& Manzini, R. (2017). Designing sustainable cold chains for long-range food distribution: Energy-effective corridors on the Silk Road Belt. Sustainability, 9(11), 2044. https://doi.org/10.3390/su9112044

Gibson, R. B. (2006). Beyond the pillars: sustainability assessment as a framework for effective integration of social, economic and ecological considerations in significant decision-making. Journal of Environmental Assessment Policy and Management, 8(03), 259-280. https://doi.org/10.1142/s1464333206002517

Göransson, M., Nilsson, F., \& Jevinger, Å. (2018). Temperature performance and food shelf-life accuracy in cold food supply chains-Insights from multiple field studies. Food Control, 86, 332-341. https://doi.org/10.1016/j.foodcont.2017.10.029

Govindan, K. (2018). Sustainable consumption and production in the food supply chain: A conceptual framework. International Journal of Production Economics, 195, 419-431. https://doi.org/10.1016/j.ijpe.2017.03.003

Grandinetti, R., \& Rullani, E. (1996). Impresa transnazionale ed economia globale. La Nuova Italia Scientifica.

Guido, G. (2017). The peculiar nature of place marketing according to an inductional approach. Plurimondi, 10.

Gupta, J., \& Vegelin, C. (2016). Sustainable development goals and inclusive development. International Environmental Agreements: Politics, Law and Economics, 16(3), 433-448. https://doi.org/10.1007/s10784-016-9323-z

Hsiao, H. I., Kemp, R. G. M., Van der Vorst, J. G. A. J., \& Omta, S. O. (2010). A classification of logistic outsourcing levels and their impact on service performance: Evidence from the food processing industry. International Journal of Production Economics, 124(1), 75-86. https://doi.org/10.1016/j.ijpe.2009.09.010

Hsiao, H. I., Van der Vorst, J. G. A. J., \& Omta, S. W. F. (2006). Logistics outsourcing in food supply chain networks. In J. Bijman et al. (Eds.), Wageningen (pp. 135-150). The Netherlands: Wageningen Academic Publishers.

Kotler, P., Haider, D. H., \& Rein, I. (1993). Marketing Places: attracting investment, industry, and tourism to cities, states and nations. New York: The Free Press.

Lamine, C., Garçon, L., \& Brunori, G. (2019). Territorial agrifood systems: A Franco-Italian contribution to the debates over alternative food networks in rural areas. Journal of Rural Studies, 68, 159-170. https://doi.org/10.1016/j.jrurstud.2018.11.007

Liu, S. Y., Yen, C. Y., Tsai, K. N., \& Lo, W. S. (2017). A conceptual framework for agri-food tourism as an eco-innovation strategy in small farms. Sustainability, $9(10), 1683$. https://doi.org/10.3390/su9101683

Marcucci, E. (2002). Le piattaforme logistiche come strumento di competitività del. Territorio. Quaderni Archivio Urbanistica, 4(117), 46-58.

Mazzeo, G. (2010). Campania: territorio e città di fronte alla sfida della logistica. Journal of Land Use, Mobility and Environment, 3(2), 17-28. ISSN 1970-9870.

Mazzeo, G. (2018). Resilienza, circolarità, sostenibilità. Urbanistica Informazioni (Special Issue X Giornata di Studio INU "Crisi e rinascita delle città", a cura di Franceco Domenico Moccia, Marichela Sepe), 272, 218-219.

Meynard, J. M., Jeuffroy, M. H., Le Bail, M., Lefèvre, A., Magrini, M. B., \& Michon, C. (2017). Designing coupled innovations for the sustainability transition of agrifood systems. Agricultural Systems, 157, 330-339. https://doi.org/10.1016/j.agsy.2016.08.002

Montella, M. M., \& Silvestrelli, P. (2020). Heritage e relationship marketing per le imprese agroalimentari italiane. Micro \& Macro Marketing, 29(1), 71-92.

Naik, G., \& Suresh, D. N. (2018). Challenges of creating sustainable agri-retail supply chains. IIMB Management Review, 30(3), 270-282. https://doi.org/10.1016/j.iimb.2018.04.001

Nematollahi, M., \& Tajbakhsh, A. (2020). Past, present, and prospective themes of sustainable agricultural supply chains: A content analysis. Journal of Cleaner Production, 271, 122201. https://doi.org/10.1016/j.jclepro.2020.122201

Nikolaou, I. E., Evangelinos, K. I., \& Allan, S. (2013). A reverse logistics social responsibility evaluation framework based on the triple bottom line approach. Journal of Cleaner Production, 56, 173-184. https://doi.org/10.1016/j.jclepro.2011.12.009 
Palmiotti, D. (2019). Con 10 milioni riparte Agromed, piattaforma logistica per l'ortofrutta. Nell'ex stabilimento tessile Miroglio processi innovativi di lavorazione dei prodotti. Il sole24ore

Paniccia, P. M., Silvestrelli, P., Leoni, L., \& Baiocco, S. (2017). Imprese agricole, territorio e turismo in sinergia per lo sviluppo sostenibile, Impresa Progetto. Electronic Journal of Management, 3.

Pastore, A., Golinelli, C. M., Ricotta, F., \& Vernuccio, M. (2002). Il marketing per lo sviluppo turistico e territoriale. I progetti Rural Tourism Network e Rural Market Place nella Comunità Montana dell'Aniene, Atti al Congresso Internazionale "Le tendenze del Marketing in Europa". Ecole Supérieure de Commerce de Paris.

Pike, A., Rodríguez-Pose, A., \& Tomaney, J. (2017). Local and Regional Development. New York: Routledge. https://doi.org/10.4324/9781315767673

Pino, G., Guido, G., Peluso, A. M., \& Pichierri, M. (2018). Assessing the strategic needs of local territorial systems (LTSs). Journal of Place Management and Development, 11(4), 463-491. https://doi.org/10.1108/jpmd-08-2017-0076

Pope, J., Annandale, D., \& Morrison-Saunders, A. (2004). Conceptualising sustainability assessment. Environmental Impact Assessment Review, 24(6), 595-616. https://doi.org/10.1016/j.eiar.2004.03.001

Pulina, P., \& Timpanaro, G. (2012). Ethics, sustainability and logistics in agricultural and agri-food economics research. Italian Journal of Agronomy, 33. https://doi.org/10.4081/ija.2012.e33

Rama, M., González-García, S., Andrade, E., Moreira, M. T., \& Feijoo, G. (2020). Assessing the sustainability dimension at local scale: Case study of Spanish cities. Ecological Indicators, 117, 106687. https://doi.org/10.1016/j.ecolind.2020.106687

Razzaque, M. A., \& Sheng, C. C. (1998). Outsourcing of logistics functions: a literature survey. International Journal of Physical Distribution \& Logistics Management, 28(3), 89-107. https://doi.org/10.1108/09600039810221667

Renigier-Biłozor, M., \& Biłozor, A. (2015). Territorial Marketing as an Element Boosting the Development of a Commune. Real Estate Management and Valuation, 23(2), 40-51. https://doi.org/10.1515/remav-2015-0014

Rifai, F., \& Hashem, A. (2018). Outsourcing Strategy of Logistical Activities as Adaptive Tool for SMEs. Journal of Management \& Sustainability, 8, 88. https://doi.org/10.5539/jms.v8n3p88

Rinaldi, C., \& Cavicchi, A. (2016). Cooperative behaviour and place branding: a longitudinal case study in Italy. Qualitative Market Research: An International Journal. https://doi.org/10.1108/QMR-02-2016-0012

Saetta, S., \& Caldarelli, V. (2020). How to increase the sustainability of the agri-food supply chain through innovations in 4.0 perspective: A first case study analysis. Procedia Manufacturing, 42, 333-336. https://doi.org/10.1016/j.promfg.2020.02.083

Seuring, S., \& Müller, M. (2008). From a literature review to a conceptual framework for sustainable supply chain management. Journal of Cleaner Production, 16(15), 1699-1710. https://doi.org/10.1016/j.jclepro.2008.04.020

Seuring, S., Sarkis, J., Müller, M., \& Rao, P. (2008). Sustainability and supply chain management-An introduction to the special issue. Journal of Cleaner Production, 16(15), 1545-1551. https://doi.org/10.1016/j.jclepro.2008.02.002

Swart, R. J., Raskin, P., \& Robinson, J. (2004). The problem of the future: sustainability science and scenario analysis. Global Environmental Change, 14(2), 137-146. https://doi.org/10.1016/j.gloenvcha.2003.10.002

Tanasă, L. (2014). Benefits of short food supply chains for the development of rural tourism in Romania as emergent country during crisis. Agricultural Economics and Rural Development, 11(2), 181-193.

The European House Ambrosetti. (2019). La creazione di valore lungo la filiera agroalimentare estesa in Italia. Position paper 2019. Retrieved May 3, 2020, from http://adm-distribuzione.it/wp-content/uploads/2019/11/Position-Paper_La-creazione-di-valore-lungo-la-fili era-agroalimentare-estesa-in-Italia.pdf

Tilman, D., \& Clark, M. (2015). Food, agriculture \& the environment: can we feed the world \& save the earth? Daedalus, 144(4), 8-23. https://doi.org/10.1162/DAED_a_00350

Tovma, N., Shurenov, N., Bimendiyeva, L., Kozhamkulova, Z., \& Akhmetova, Z. (2020). Territorial marketing 
and its role in determining regional competitiveness. Evaluating supply chain management. Uncertain Supply Chain Management, 8(1), 1-16. https://doi.org/10.5267/j.uscm.2019.10.001

Ugolini, P. (2010). Approccio alla sostenibilità nella governance del territorio. F. Angeli.

Vaccà, S., \& Cozzi, G. (2002). Come governare la globalizzazione dello sviluppo economico. Economia \& Management, 4(61).

Valdani, E., \& Bertoli, G. (2006). Mercati internazionali e Marketing. Egea, Milano.

Van Damme, D. E., \& Van Amstel, M. J. P. (1996). Outsourcing logistics management activities. International Journal of Logistics Management, 7(2), 85-95. https://doi.org/10.1108/09574099610805548

Van der Vorst, J. G. A. J., Beulens, A. J. M., \& Beek, P. V. (2005). Innovations in logistics and ICT in food supply chain networks. In W. M. F. Jongen \& M. T. G. Meulenberg (Eds.), Innovation in Agri-Food Systems (pp. 245-292). Wageningen, Wageningen Adademic Publishers.

Verdouw, C. N., Robbemond, R. M., Verwaart, T., Wolfert, J., \& Beulens, A. J. (2015). A reference architecture for IoT-based logistic information systems in agri-food supply chains. Enterprise Information Systems, 12(7), 755-779. https://doi.org/10.1080/17517575.2015.1072643

Vrat, P., Gupta, R., Bhatnagar, A., Pathak, D. K., \& Fulzele, V. (2018). Literature review analytics (LRA) on sustainable cold-chain for perishable food products: research trends and future directions. Opsearch, 55(3-4), 601-627. https://doi.org/10.1007/s12597-018-0338-9

Wiskerke, J. S. (2009). On places lost and places regained: Reflections on the alternative food geography and sustainable regional development. International Planning Studies, 14(4), 369-387. https://doi.org/10.1080/13563471003642803

Zanoni, S., \& Zavanella, L. (2012). Chilled or frozen? Decision strategies for sustainable food supply chains, International Journal of Production Economics, 140(2), 731-736. https://doi.org/10.1016/j.ijpe.2011.04.028

\section{Copyrights}

Copyright for this article is retained by the author, with first publication rights granted to the journal.

This is an open-access article distributed under the terms and conditions of the Creative Commons Attribution license (http://creativecommons.org/licenses/by/4.0/). 